\title{
Does gender diversity on firm's board affect dividend payouts? Evidence from India
}

\author{
Kalyani Mulchandani ${ }^{1}$, Ketan Mulchandani ${ }^{2}$ and Sahil Singh Jasrotia ${ }^{3^{*}}$ (])
}

\begin{abstract}
This study attempts to determine whether gender diversity on the firm's board affects the dividend payout ratio concerning firms listed on Nifty 50 in India. Multiple regression analysis and the logit model have been employed. The dependent variable is the dividend payout policy of the firm, and the independent variable is gender diversity. The regression model incorporated control variables that have been popularly listed in the extant literature. The robustness of the results has also been tested. It was found that there exists a positive association between the percentage of female directors and the dividend payout ratio. Results also found that there is a positive impact of the number of female directors on the dividend to total assets. This implies that gender diversity on board positively affects the payout ratio of firms. This study is the first of its kind to investigate the association of gender diversity on the firm's board and dividend payout ratio.
\end{abstract}

Keywords: Gender diversity, Dividend payout ratio, Percentage of female directors

\section{Introduction}

In the past, several researchers have noticed that corporate governance influences the dividend payout ratio [6,22]. Chen et al. [12] conducted a study to assess corporate governance's impact on dividend policy and found that gender diversity is not taken into account while studying corporate governance. Therefore, Chen et al. [12] conducted research to fill this gap, but this study was conducted on US companies' sample firms. In India also, this topic has not gained much importance. Several studies have been conducted in the past which investigated the effect of board size [52], CEO duality [48], gender [44, 45] on the dividend policy of the firm. However, very few studies examine the effect of gender diversity of board on dividend payout. As per our knowledge, no such study was conducted only on Indian firms that examine the impact of female representation on board on dividend payout ratio. India is an emerging market,

\footnotetext{
*Correspondence: sahiljasrotia93@gmail.com

${ }^{3}$ Marketing, Jaipuria Institute of Management, Indore, India Full list of author information is available at the end of the article
}

and the institutional setting is not the same as it was in earlier years. Regulators, at their level, are making an effort to protect the interest of shareholders. Thus, this study is undertaken to analyze the association of female proportion on board and dividend payout ratio in Indian context.

The quality of corporate governance has a major role in defining the firm's dividend policy [2]. If a firm doesn't pay dividends, these funds can be diverted to other projects where managers' personal interest lies, which suggests that investors prefer dividends over retained earnings [55]. A study by Hiller and Shackelford [27] stated that managers may utilize a firm's resources that benefit them rather than shareholders. The dividend policy also addresses the agency problem conflicts that exists between corporate insiders and shareholders outside [16]. Paying higher cash dividends to the shareholders reduces the amount of cash available to the firm, minimizing the agency problems [7]. This suggests that to minimize agency problems, managers should pay higher cash dividends. Now, the query is why the managers would declare higher dividends when they tend to retain cash? So, this can be made 
possible when the firm has people on board of varied characteristics in terms of gender, background, and experiences to influence the board decisions.

Many firms have realized that gender diversity boosts the performance of firms (Hindu Business Line, 2018). According to a survey conducted on 2400 global firms by Credit Suisse in 2012, firms with at least one-woman director on board have a higher net income growth and earned a higher return on equity than those firms that do not have woman directors on their board. The report also reported that firms with at least one-woman director on board have a higher price/book value ratio, better average growth, and lower gearing.

According to a study conducted in 2016 by global recruitment firm myhiringclub.com and job portal, India, with a rank of 26th, has only 6.9 percent of women directors. Norway has 40.1 percent of women directors on their board followed by Sweden with 29.3 percent. This percent in India has gone up to $15 \%$ till January 2018 which shows a sway in this. Globally, the average age of woman directors is less than the average age of male directors on board, whereas, in India, this difference is higher than in global firms.

As per the Indian Boards Database covering 1819 NSE listed companies, 73 firms are yet to induct women directors on board. In the remaining firms, only 2347 directorship positions are held by women out of 13,910 total directorship positions, which is $16.87 \%$. Female presence across these companies is 1903 on 11,294 individuals, which is almost equal to $17 \%$. However, this number of female directors is expected to increase, because as per the Companies Act 2013 of India, it is compulsory to appoint at least one-woman director on the board if the company is listed on the stock exchange or if the paid-up capital of a company is more than one hundred crore rupees. In April 2014, SEBI also issued a mandate for listed firms to appoint at least one female director on board by March 2015 (Economic Times, 2016). After that date was extended to June 2015, failure to comply with this norm will attract financial penalties. Still, many firms are yet to induct female directors on board. The female director on board gives innovative ideas [53] and gives a different perspective [54].

To analyze the association of female representation on board and dividend payout, the logit model is used for estimation when the dependent variable is binary, and in the rest of the models, multiple regression analysis is performed. The results of the study indicate that the composition of BOD affects the dividend payout ratio. Firms with a higher percentage of female directors on board are inclined toward paying higher dividends against the ones with lesser female directors on board.

\section{Institutional setting}

SEBI in India has made it mandatory to form a dividend distribution policy for the top 500 listed firms. This policy will benefit the investor in knowing a clearer picture of utilizing a firm's profits (Economic Times, 2016). Regulators are making efforts to protect the interests of shareholders by inculcating amendments.

Gallego-Alvarez et al. [19] bring out that a matter of corporate governance is not generalized across various countries but needs to be examined considering individual countries' points of view as they differ on various parameters legal, economic, and financial. Dividend Distribution Tax was introduced in India in the Finance Act 1997, and later on, the government made certain amendments in the way it is levied. The inflation rate and the fiscal deficit have decreased in the past few years. Adding to this, India's speedy economic growth and development may make this USD 5 trillion economy in the coming five years (Hindu Business Line, 2019). It is mandatory to have a woman director on board in India if it is a listed firm or if its paid-up capital is Rs.100 crore or more, or if the firm's turnover is Rs. 300 crore or more. As per the Listing Regulations, the top 500 listed firms must appoint at least one female independent by April 1, 2019, and this deadline is extended to April 1, 2020, for the top 1000 firms. To ensure this, listed firms are required to make quarterly disclosure of the gender of the board members to the stock exchange. India has observed a drastic change in the dividend-paying behavior of firms. This can be said as the remarkable decline is present in the percentage of companies paying a dividend. It has declined to approx. 65 percentages in 2013 from approx. 81 percentages in 1995 [31].

\section{Dividend payouts and gender diversity}

Earlier studies have reported that a female's presence on board makes a firm socially responsible [33]. Past studies indicate that firms with larger percentage of women presence on board have a better reputation $[40,46]$. Terjesen et al. [51] reported that the female proportion on board has a direct impact on the firm's value. Various researches have also been conducted determining the association between female presence on board and governance issues. A higher number of women on board have a higher level of public disclosure [4], better supervision of managers [17], higher earnings quality [10], promote informed decisions [50]. According to Lara et al. [34], female directors display more independent thinking and raise the monitoring process. Solimene et al. [47] also proved that females on board have lesser attendance problems as compare to their counterparts. Additionally, 
males' attendance behavior on board also improves when a higher proportion of female representation is there. Together, the results indicate that boards having gender diversity have a higher possibility of making rational decisions and minimizes agency problems by protecting shareholders' interest and eventually set higher DPR (dividend payout ratio). Therefore, to safeguard shareholders' interest, regulations in many countries (Belgium, France, Germany, Iceland, India, Israel, Italy, Norway, and Spain) have made it compulsory to have gender diversity on board for public listed firms [37].

A study by Pucheta-Martínez and Bel-Oms [44] has found a positive relationship between dividend payout and the proportion of woman directors on board. The study also found no effect of female independent executive directors on dividend payout while there is a negative impact found of female institutional directors on dividend payout. On the other hand, Saeed and Sameer [45] found that in emerging economies like India, China, and Russia, gender diversity on firm's board has a negative relation with cash dividend payments. This signifies that there are mixed results.

Gyapong et al. [24] concluded that the gender of the BOD is negatively correlated with dividend payout. Pucheta-Martínez and Bel-Oms [44] conducted a study on Spanish firms found that gender diversity on boards positively affects dividend payout of firm. Similar results are obtained by Byoun [9] in his study conducted on US firms. Pahi and Yadav [42] also found a significant positive association between DPR (dividend payout ratio) and gender diversity on board of S \& P 500 firms. A study by Campbell and Vera [11] also reflected that US firms with a higher proportion of female directors onboard display lower agency cost and distribute higher dividends. Raising corporate governance and creating board more diversified uplifts dividend payments and increases payout ratio [3]. Chen et al. [12] conducted a study on firms listed in the U.S. and found that firms pay larger dividends with more female independent directors.

Gender Diversity is important for corporate level outcomes as women act diligently are risk averse and are more careful while taking decisions for a firm [39]. Other studies have also indicated that female representation on board strengthen corporate governance which leads to increased transparency and also enhances confidence of stakeholders [18]. Based on the above literature, the following hypothesis can be formed:

Hypothesis 1 Gender diversity on board positively affects dividend payout ratio.

\section{Methods}

Data are extracted from Bloomberg Professional Account, CMIE Prowess, and the company's annual report for 10 years from the year 2010 to year 2019. Firms listed on Nifty 50 are taken into consideration which makes a total of 500 firm-year observations. Measurement of dependent, independent, and control variables is given in Table 1. Logit model is used for estimation when the dependent variable is binary, and in the rest of the models, multiple regression analysis is performed.

Dependent variable: Following [12], three measures of dividends are taken:

(a) dividends, whether the firm is paying a dividend or not (b) dividend payout ratio, which is measured by cash dividends/net income and (c) dividends over total assets which is measured as cash dividends over total assets.

DIV: Dummy variable one if the firm pays dividends, otherwise 0.

DPR: Dividend payout ratio i.e., Dividends/Earnings. DPRTA: Dividends Paid to Total Assets.

Independent Variable: The Independent Variable considered for the study is Gender Diversity, and following variables are taken for measuring gender diversity.

DIRF: Female directors on board.

DIRFPER: Percentage of female directors on board.

DIRFLN: Natural Log of female directors on board plus one.

FD1: Dummy variable 1 if at least one female director is on board, otherwise 0 .

FD3: Dummy variable 3 if at least three female directors are on board, otherwise 0 .

The following study by Gul et al. [23], proxy for gender diversity on board is considered. Adding to it, two dummy variables are added which are FD1 and FD3. Zalata et al. [56] suggests that one is a mere representation, two indicates the presence and, three is a voice.

\section{Control variables}

Natural Logarithm of total assets (TALOG): Firm size is measured by determining the natural log of total assets. Many previous studies [14, 55] have found a positive association between the firm's payout of earnings and size. The reason for obtaining a positive relationship is that large firms may have higher earnings than small-sized firms, suggesting that big-sized firms have more potential to pay dividends. Another reason can be, Distribution of profits is one of the ways to minimize agency conflicts; therefore, large-size firms 
Table 1 Variables description

\begin{tabular}{|c|c|}
\hline Variable & Proxy \\
\hline \multicolumn{2}{|c|}{ Panel A: Dividend proxy } \\
\hline DIV & One if dividend is paid by firm, else zero \\
\hline DPR & Dividends Paid/Net Income \\
\hline DPRTA & Dividends Paid/Total Assets \\
\hline PASTDIV & One if firm has paid dividend in last year and current year, else zero \\
\hline DPRINC & One is dividend payout ratio has increased from last year, else zero \\
\hline DPRTAINC & One if ratio of Dividends Paid/Total Assets has increased from last year, else zero \\
\hline \multicolumn{2}{|c|}{ Panel B: Gender diversity proxy } \\
\hline DIRF & Number of Female Directors on the board \\
\hline DIRFLN & Natural Log of female directors on board plus one \\
\hline DIRFPER & Percentage of female directors to total directors on board \\
\hline FD1 & One if minimum one female director is on board, else zero \\
\hline FD3 & One if minimum three female director is on board, else zero \\
\hline \multicolumn{2}{|c|}{ Panel C: Other variables } \\
\hline TALOG & Natural logarithm of total assets \\
\hline FINLEV & Financial leverage measured by total debts/total assets \\
\hline TOBINSQ & $\begin{array}{l}\text { Tobin's } Q \text { measured by (total assets-book value of equity + market value of } \\
\text { equity)/total assets }\end{array}$ \\
\hline ROA & Net income/total assets \\
\hline RETE & retained earnings/total common equity \\
\hline CASHHOL & Cash holdings measured by (cash + current investment)/total assets \\
\hline MARTOBOOK & Market-to-book: natural logarithm of total market value/total assets \\
\hline LOGDIR & Logarithm of the total number of board directors \\
\hline LOGINDIRBS & Logarithm of the number of independent directors divided by board size \\
\hline
\end{tabular}

may adopt this mechanism to handle agency problems [25].

Financial Leverage (FINLEV): Financial Leverage is measured as total debts to total assets. Literature shows that firms with high financial leverage pay smaller dividends [32, 36]. Highly leveraged firms are subject to close monitoring from lenders and creditors, and also cost of raising finance from outside is high. That is why high leveraged firms are inclined to pay lesser dividends and retain high profits. Therefore, the association of financial leverage and payout ratio is negative.

Tobins $Q$ and $M B$ Ratio: $\mathrm{MB}$ is the ratio of market to book value of equity. Lai et al.35] found that the MB ratio is negatively associated with dividend payments for active Egyptian firms, and vice-versa results were obtained for non-active firms. Contrary to this, a study conducted by He and Wintoki [26] on US firms found a positive association of $\mathrm{MB}$ on dividend payments. Results are assorted in this context.

ROA: ROA denotes return on assets which is measured as net income to total assets [49]. This is a measure of profitability. Profitability is expected to affect the payout ratio positively. Firms are less inclined to increase dividends unless the firm's earnings increase. Many studies show that the payout ratio and profitability are positively related $[1,5]$.

Retained Earnings to Total Common Equity (RETE): Firms that are profitable and not having investment opportunities are more likely to distribute profits to shareholders. Contrary to this, firms at a growing stage in their life cycle may not prefer to pay dividends. This is consistent with the results obtained from the study of Kim and Kim [30, in their study suggested that firms having a lower ratio of RETE are the ones that are planning to increase their asset/investments, thereby having a lower ratio of RETE. In contrast, a higher ratio is obtained for firms in the maturity phase and not having expansion opportunities. It is expected to have a positive association with RETE and dividends.

Cash: This indicates cash holdings of a firm, which includes cash balance, bank balance, and short term financial investments. Total assets deflate this. Paying dividends will reduce the balance of cash holdings, which may prevent management from misusing the funds. Therefore, investors prefer receiving dividends. This also minimizes agency conflicts. Previous research $[20,21]$ 
also indicates that managers' actions can be controlled by distributing excess cash of a firm either as paying dividends or share repurchase. This is consistent with the results obtained from the study of Li et al. [35]. On the contrary, Dogru [15] suggested that firms with expansion plans can also hold a large amount of cash and need not pay dividends. This implies that results are mixed about the association of cash and dividend payout.

Log of Total Number of Board Directors(LOGDIR) and Log of the number of independent directors divided by board size(LOGINDIRBS): Agency theory suggests that board size shall be kept small for efficient functioning [43]. On the other hand, resource dependence theory proposes a bigger board size for more deliberations and better decision-making [41]. That is why two variables are added: board size and percentage of independent directors on board to record the impact of independent board members and the standard of corporate governance [12].

\section{Results and discussion}

Looking at Table 2, this can be inferred that most of the firms in India pay a dividend.

Out of 500 firm's yearly observations, 476 are dividend-paying firms, and 24 are non-dividend-paying firms. Also, on average, $40 \%$ of earnings are paid out as dividends, and skewness is also present in DIVEARN. On average, $4 \%$ of total assets are paid out as cash dividends, and a skewness value of 5.934258 indicates that data are

Table 2 Descriptive statistics

\begin{tabular}{llllc}
\hline Variable & Mean & Median & SD & Skewness \\
\hline DIV & 1 & 1 & 0.21398 & -4.24165 \\
DIVEARN & 0.393634 & 0.254969 & 0.910766 & 12.38541 \\
DIVTA & 0.041631 & 0.01514 & 0.082016 & 5.934258 \\
PASTDIV & 0.153846 & 0 & 0.375534 & 2.178717 \\
DPRINC & 0.375 & 0 & 0.5 & 0.571429 \\
DPRTAINC & 0.277778 & 0 & 0.460889 & 1.084861 \\
DIRF & 1.204792 & 1 & 0.961737 & 0.91812 \\
DIRFLN & 1.031682 & 1 & 0.671806 & -0.06407 \\
DIRFPER & 0.067627 & 0.0833 & 0.050338 & 0.127579 \\
FD1 & 0.986486 & 1 & 0.11572 & -8.4844 \\
FD3 & 0.084 & 0 & 0.277666 & 3.008444 \\
TALOG & 12.94599 & 12.94507 & 1.57865 & 0.081538 \\
FINLEV & 0.890007 & 0.399066 & 3.152512 & 7.09032 \\
TOBINSQ & 1.36919 & 1.342467 & 0.88789 & 0.337879 \\
ROA & 0.099629 & 0.070839 & 0.101888 & 2.16955 \\
RETE & 0.790593 & 0.853554 & 0.200317 & -0.8091 \\
CASHHOL & 0.121878 & 0.036324 & 0.493102 & 10.64047 \\
MARTOBOOK & 3.602232 & 2.116184 & 4.408416 & 5.198927 \\
LOGDIR & 1.052306 & 1.079181 & 0.115394 & -0.27845 \\
LOGINDIRBS & 0.284269 & 0.273028 & 0.118359 & 1.184883 \\
\hline
\end{tabular}

highly asymmetric. It is surprising to see that the average number of female directors on board is around 1. In percentage terms, only $6.7 \%$ of directors are female, which is meager. Most of the variables are skewed, either positively or negatively, so data are asymmetric.

Table 3 shows that there is no statistically significant difference in the means of dividend-paying and non-dividend-paying firms in the dependent variable and independent variable except FD1. The difference in mean of control variable: $\log$ of total assets, financial leverage, return on assets, cash holding, and retained earnings to total equity are statistically significant.

Model for Testing Impact of Board Gender Diversity and Dividend Payout Policy.

Panel 1 (A)

$$
\begin{aligned}
\text { DIV }= & \beta_{0}+\beta_{1} \text { LOGDIR }_{i t}+\beta_{2} \text { LOGINDIRBS }_{\text {it }} \\
& +\beta_{3} \text { TALOG }_{i t}+\beta_{4} \text { FINLEV }_{\text {it }} \\
& +\beta_{5} \text { MARTOBOOK }_{i t}+\beta_{6} \text { ROA }_{i t} \\
& +\beta_{7} \text { RETE }_{i t}+\beta_{8} \text { CASHHOL }_{i t} \\
& +\beta_{9} \text { TOBINSQ }_{i t}+e_{\mathrm{t}}
\end{aligned}
$$

$$
\begin{aligned}
\text { DIV }= & \beta_{0}+\beta_{1} \text { DIRF }_{i t}+\beta_{2} \text { LOGDIR }_{i t} \\
& +\beta_{3} \text { LOGINDIRBS }_{\text {it }} \\
& +\beta_{4} \text { TALOG }_{i t}+\beta_{5} \text { FINLEV }_{i t} \\
& +\beta_{6} \text { MARTOBOOK }_{i t}+\beta_{7} \text { ROA }_{\text {it }} \\
& +\beta_{8} \text { RETE }_{i t}+\beta_{9} \text { CASHHOL }_{i t} \\
& +\beta_{10} \text { TOBINSQ }_{i t}+e_{\mathrm{t}}
\end{aligned}
$$

Table 3 Mean difference test

\begin{tabular}{llllll}
\hline Variables & DIV $=\mathbf{1}$ & Mean & DIV $=\mathbf{0}$ & Mean & \multicolumn{1}{l}{ Diff } \\
\hline DIRF & 476 & 1.197706 & 24 & 1.345317 & -0.1476104 \\
DIRFLN & 476 & 1.023684 & 24 & 1.190302 & -0.1666176 \\
DIRFPER & 476 & 0.07 & 24 & 0.08 & -0.008 \\
FD1 & 476 & 0.77 & 24 & 0.96 & $* * *-0.185$ \\
FD3 & 476 & 0.278 & 24 & 0.282 & 0.001 \\
TALOG & 476 & 12.91693 & 24 & 13.522263 & $*-0.6053333$ \\
FINLEV & 476 & 0.912658 & 24 & 0.440755 & $* * * .4719026$ \\
TOBINSQ & 476 & 1.37990424 & 1.156699 & 0.2232053 \\
ROA & 476 & 0.10190924 & 0.054409 & $* * .0475003$ \\
RETE & 476 & 0.79853924 & 0.632996 & $* * * .1655434$ \\
CASHHOL & 476 & 0.12641524 & 0.031907 & $* * * .0945075$ \\
MARTOBOOK & 476 & 3.62946 & 24 & 3.062214 & 0.5672464 \\
LOGDIR & 476 & 1.054089 & 24 & 1.016943 & 0.0371468 \\
LOGINDIRBS & 476 & 0.284535 & 24 & 0.278999 & 0.0055356 \\
\hline
\end{tabular}

***, **, ${ }^{*}$ Significance at $1 \%, 5 \%$ and $10 \%$ 


$$
\begin{aligned}
\text { DIV }= & \beta_{0}+\beta_{1} \text { DIRFPER }_{i t}+\beta_{2} \text { LOGDIR }_{i t} \\
& +\beta_{3} \text { LOGINDIRBS }_{i t}+\beta_{4} \text { TALOG }_{i t}+\beta_{5} \text { FINLEV }_{\text {it }} \\
& +\beta_{6} \text { MARTOBOOK }_{i t}+\beta_{7} \text { ROA }_{\text {it }}+\beta_{8} \text { RETE }_{i t} \\
& +\beta_{9} \text { CASHHOL }_{i t}+\beta_{10} \text { TOBINSQ }_{i t}+e_{\mathrm{t}}
\end{aligned}
$$

$$
\begin{aligned}
\text { DIV }= & \beta_{0}+\beta_{1} \text { FD }_{i t}+\beta_{2} \text { LOGDIR }_{i t}+\beta_{3} \text { LOGINDIRBS }_{i t} \\
& +\beta_{4} \text { TALOG }_{i t}+\beta_{5} \text { FINLEV }_{\text {it }}+\beta_{6} \text { MARTOBOOK }_{i t} \\
& +\beta_{7} \text { ROA }_{i t}+\beta_{8} \text { RETE }_{i t}+\beta_{9} \text { CASHHOL }_{i t} \\
& +\beta_{10} \text { TOBINSQ }_{i t}+e_{\mathrm{t}}
\end{aligned}
$$

Logit regression analysis is performed for Panel 1(A). The number of female directors on board and the percentage of female directors on board are positively impacting DIV. DIRFPER has a co-efficient of (2.795) which is statistically significant at $5 \%$. It is estimated that firms with a higher percentage of female directors do not prefer paying dividends. In the Indian context, it is observed that larger firms have negative co-efficient, which suggests that firms with a higher asset base prefer not paying dividends. This is contrary to the results obtained by Jiraporn et al. [29], in their study, it was found that larger firms are more likely to pay dividends. Results also suggest that independent directors are in favor of paying out dividends to shareholders. The reason for independent directors preferring to pay dividends can be attributed to minimizing the agency conflicts. It is important to note that FD1 is not a significant variable, suggesting that one female director on board acts only as a representative. This was also opined by De Cabo et al. [13]. Results are consistent with the study of Huang and Paul [28] in context to CASHHOL. Firms holding high cash had paid dividends. To add, firms that have a high ratio of RETE are prone to paying dividends.

Model for Testing Impact of Board Gender Diversity and Dividend Payout Policy.

Panel 1 (B)

$$
\begin{aligned}
\text { DIVEARN }= & \beta_{0}+\beta_{1} \text { LOGDIR }_{i t}+\beta_{2} \text { LOGINDIRBS }_{i t} \\
& +\beta_{3} \text { TALOG }_{i t}+\beta_{4} \text { FINLEV }_{i t} \\
& +\beta_{5} \text { MARTOBOOK }_{i t}+\beta_{6} \text { ROA }_{i t} \\
& +\beta_{7} \text { RETE }_{i t}+\beta_{8} \text { CASHHOL }_{i t} \\
& +\beta_{9} \text { TOBINSQ }_{i t}+e_{\mathrm{t}}
\end{aligned}
$$

$$
\begin{aligned}
\text { DIVEARN }= & \beta_{0}+\beta_{1} \text { DIRF }_{\text {it }}+\beta_{2} \text { LOGDIR }_{\text {it }} \\
& +\beta_{3} \text { LOGINDIRBS }_{\text {it }}+\beta_{4} \text { TALOG }_{i t} \\
& +\beta_{5} \text { FINLEV }_{\text {it }}+\beta_{6} \text { MARTOBOOK }_{i t} \\
& +\beta_{7} \text { ROA }_{i t}+\beta_{8} \text { RETE }_{i t}+\beta_{9} \text { CASHHOL }_{i t} \\
& +\beta_{10} \text { TOBINSQ }_{i t}+e_{\mathrm{t}}
\end{aligned}
$$

$$
\begin{aligned}
\text { DIVEARN }= & \beta_{0}+\beta_{1} \text { DIRFPER }_{i t}+\beta_{2} \text { LOGDIR }_{i t} \\
& +\beta_{3} \text { LOGINDIRBS }_{\text {it }}+\beta_{4} \text { TALOG }_{i t} \\
& +\beta_{5} \text { FINLEV }_{\text {it }}+\beta_{6} \text { MARTOBOOK }_{\text {it }} \\
& +\beta_{7} \text { ROA }_{i t}+\beta_{8} \text { RETE }_{i t} \\
& +\beta_{9} \text { CASHHOL }_{i t}+\beta_{10} \text { TOBINSQ }_{i t}+e_{\mathrm{t}}
\end{aligned}
$$

$$
\begin{aligned}
\text { DIVEARN }_{=} & \beta_{0}+\beta_{1} \text { FD }_{\text {it }}+\beta_{2} \text { LOGDIR }_{\text {it }} \\
& +\beta_{3} \text { LOGINDIRBS }_{\text {it }}+\beta_{4} \text { TALOG }_{i t} \\
& +\beta_{5} \text { FINLEV }_{\text {it }} \\
& +\beta_{6} \text { MARTOBOOK }_{i t}+\beta_{7} \text { ROA }_{i t} \\
& +\beta_{8} \text { RETE }_{i t} \\
& +\beta_{9} \text { CASHHOL }_{i t}+\beta_{10} \text { TOBINSQ }_{i t}+e_{\mathrm{t}}
\end{aligned}
$$

In Panel 1(b), the estimated coefficient is positive for female directors and the percentage of female directors on board. This co-efficient is also significant at $5 \%$ and $1 \%$, respectively. The dividend payout ratio and percentage of female directors on board are positively associated. This is inconsistent with Chen et al. [12] results, where they conducted a study in Chinese institutional settings, whereas in the Indian context, results are contrary. Like the output of $1(\mathrm{~A}), \mathrm{FD}$ is not a significant variable, restating Kristie's result, 2011. Return on Assets is significant in 1(b)-(i) and 1 (b)-(ii), and it is an insignificant variable when the percentage of female directors is considered in panel 1(b)-(iii) and FD1 in panel 1(b)-iv.

Model for Testing Impact of Board Gender Diversity and Dividend Payout Policy.

Panel 1 (C)

$$
\begin{aligned}
\text { DIVTA } & =\beta_{0}+\beta_{1} \text { DIRF }_{i t}+\beta_{2} \text { LOGDIR }_{i t} \\
& +\beta_{3} \text { LOGINDIRBS }_{\text {it }}+\beta_{4} \text { TALOG }_{i t}+\beta_{5} \text { FINLEV }_{i t} \\
& +\beta_{6} \text { MARTOBOOK }_{i t}+\beta_{7} \text { ROA }_{i t}+\beta_{8} \text { RETE }_{i t} \\
& +\beta_{9} \text { CASHHOL }_{i t}+\beta_{10} \text { TOBINSQ }_{i t}+e_{\mathrm{t}}
\end{aligned}
$$

$$
\begin{aligned}
\text { DIVTA }= & \beta_{0}+\beta_{1} \text { DIRF }_{i t}+\beta_{2} \text { LOGDIR }_{\text {it }} \\
& +\beta_{3} \text { LGGINDIRBS }_{\text {it }}+\beta_{4} \text { TALOG }_{i t}+\beta_{5} \text { FINLEV }_{\text {it }} \\
& +\beta_{6} \text { MARTOBOOK }_{\text {it }}+\beta_{7} \text { ROA }_{\text {it }}+\beta_{8} \text { RETE }_{\text {it }} \\
& +\beta_{9} \text { CASHHOL }_{i t}+\beta_{10} \text { TOBINSQ }_{i t}+e_{\mathrm{t}}
\end{aligned}
$$

$$
\begin{aligned}
\text { DIVTA }= & \beta_{0}+\beta_{1} \text { DIRFPER }_{i t}+\beta_{2} \text { LOGDIR }_{i t} \\
& +\beta_{3} \text { LOGINDIRBS }_{i t}+\beta_{4} \text { TALOG }_{i t}+\beta_{5} \text { FINLEV }_{\text {it }} \\
& +\beta_{6} \text { MARTOBOOK }_{i t}+\beta_{7} \text { ROA }_{i t}+\beta_{8} \text { RETE }_{i t} \\
& +\beta_{9} \text { CASHHOL }_{i t}+\beta_{10} \text { TOBINSQ }_{i t}+e_{\mathrm{t}}
\end{aligned}
$$

$$
\begin{aligned}
\text { DIVTA }= & \beta_{0}+\beta_{1} \text { FDI }_{\text {it }}+\beta_{2} \text { LOGDIR }_{\text {it }} \\
& +\beta_{3} \text { LOGINDIRBS }_{\text {it }}+\beta_{4} \text { TALOG }_{i t}+\beta_{5} \text { FINLEV }_{\text {it }} \\
& +\beta_{6} \text { MARTOBOOK }_{\text {it }}+\beta_{7} \text { ROA }_{i t}+\beta_{8} \text { RETE }_{i t} \\
& +\beta_{9} \text { CASHHOL }_{i t}+\beta_{10} \text { TOBINSQ }_{i t}+e_{\mathrm{t}}
\end{aligned}
$$


Table 4 Board gender diversity and dividend payout policy

\begin{tabular}{|c|c|c|c|c|}
\hline Panel 1(A) & DIV & DIV & DIV & DIV \\
\hline DIRF & & -0.191 & & \\
\hline DIRFPER & & & $(2.795)^{* *}$ & \\
\hline FD1 & & & & -1.92 \\
\hline LOGDIR & $3.861^{*}$ & $4.402^{*}$ & $3.894^{*}$ & 4.654 \\
\hline LOGINDIRBS & $0.109^{* *}$ & $0.133^{* *}$ & $0.156^{* *}$ & 0.174 \\
\hline TALOG & $(0.41)^{* *}$ & $(0.376)^{*}$ & $(0.356)^{*}$ & -0.273 \\
\hline FINLEV & 0.13 & 0.095 & 0.114 & 0.184 \\
\hline MARTOBOOK & 0.189 & 0.176 & 0.171 & 0.17 \\
\hline $\mathrm{ROA}$ & -1.198 & -0.41 & -0.03 & 0.135 \\
\hline RETE & $3.332^{* * *}$ & $3.185^{* * *}$ & $3.105^{* * *}$ & 3.138 \\
\hline CASHHOL & $14.522^{* *}$ & $13.757^{* *}$ & $13.446^{* *}$ & 12.146 \\
\hline TobinsQ & -0.104 & -0.1 & -0.096 & -0.073 \\
\hline Psuedo R-Square & 0.175 & 0.178 & 0.18 & 0.205 \\
\hline Panel 1(B) & DIVEARN & DIVEARN & DIVEARN & DIVEARN \\
\hline DIRF & & $(0.018)^{* *}$ & & \\
\hline DIRFPER & & & $(.642)^{* * *}$ & \\
\hline FD1 & & & & 0.013 \\
\hline LOGDIR & -0.013 & -0.151 & -0.111 & -0.112 \\
\hline LOGINDIRBS & 0.042 & 0.334 & 0.339 & 0.331 \\
\hline TALOG & 0.094 & 0.053 & 0.052 & 0.053 \\
\hline FINLEV & 0.05 & 0.014 & 0.013 & 0.014 \\
\hline MARTOBOOK & 0.059 & 0.002 & $0.002^{* *}$ & 0 \\
\hline $\mathrm{ROA}$ & $0.128^{* *}$ & $1.12^{* *}$ & 1.114 & 1.14 \\
\hline RETE & 0.017 & 0.085 & 0.085 & 0.077 \\
\hline CASHHOL & -0.057 & -0.099 & -0.096 & -0.103 \\
\hline TobinsQ & 0 & 0.011 & 0.011 & 0.012 \\
\hline Adjusted R-Square & 0.003 & 0.001 & 0.001 & 0.001 \\
\hline Panel 1(C) & DIVTA & DIVTA & DIVTA & DIVTA \\
\hline DIRF & & $\left(0.004^{*}\right)$ & & \\
\hline DIRFPER & & & $(0.663)^{* *}$ & \\
\hline FD1 & & & & -0.004 \\
\hline LOGDIR & -0.005 & 0.007 & -0.002 & -0.002 \\
\hline LOGINDIRBS & $0.037^{* *}$ & $0.035^{*}$ & $0.034^{*}$ & $0.035^{*}$ \\
\hline TALOG & $0.007^{* * *}$ & $0.007^{* * *}$ & $0.008^{* * *}$ & $0.007^{* * *}$ \\
\hline FINLEV & 0.001 & 0.001 & 0.001 & 0.001 \\
\hline MARTOBOOK & 0.005 & 0.004 & 0.004 & 0.005 \\
\hline $\mathrm{ROA}$ & $0.669^{* * *}$ & $0.674^{* * *}$ & $0.676^{* * *}$ & $0.669^{* * *}$ \\
\hline RETE & $(0.042)^{* * *}$ & $(0.044)^{* * *}$ & $(0.044)^{* * *}$ & $(0.042)^{* * *}$ \\
\hline CASHHOL & -0.002 & -0.004 & -0.004 & -0.003 \\
\hline TobinsQ & $0.001^{*}$ & $0.002^{*}$ & $0.002^{* *}$ & $0.002^{*}$ \\
\hline Adjusted R-Square & 0.663 & 0.665 & 0.666 & 0.663 \\
\hline
\end{tabular}

***, ${ }^{* *},{ }^{*}$ Significance at $1 \%, 5 \%$ and $10 \%$ 
Referring to Table 4, the output of panel 1(c) also shows the positive impact of the number of female directors on the dividend to total assets. The co-efficient is (0.004) which is significant at $10 \%$. The percentage of female directors is also a statistically significant variable. The control variable which is positive and significant is the percentage of independent directors, size of the firm, and return on assets, whereas retained earnings to total equity have a significant negative coefficient (Table 5).

Robustness check of Model 1.
Panel 2 (A)

$$
\begin{aligned}
\text { DIV }= & \beta_{0}+\beta_{1} \text { DIRFLN }_{i t}+\beta_{2} \text { TALOG }_{i t} \\
& +\beta_{3} \text { FINLEV }_{i t}+\beta_{4} \text { MARTOBOOK }_{\mathrm{it}}+\beta_{5} \text { ROA }_{\mathrm{it}} \\
& +\beta_{6} \text { RETE }_{\mathrm{it}}+\beta_{7} \text { CASHHOL }_{\mathrm{it}}+\beta_{8} \text { TOBINSQ }_{\mathrm{it}}+e_{\mathrm{t}}
\end{aligned}
$$

$$
\begin{aligned}
\mathrm{DIV}= & \beta_{0}+\beta_{1} \mathrm{FD}_{\mathrm{it}}+\beta_{2} \text { TALOG }_{\mathrm{it}} \\
& +\beta_{3} \text { FINLEV }_{\mathrm{it}}+\beta_{4} \text { MARTOBOOK }_{\mathrm{it}}+\beta_{5} \mathrm{ROA}_{\mathrm{it}} \\
& +\beta_{6} \text { RETE }_{\mathrm{it}}+\beta_{7} \text { CASHHOL }_{\mathrm{it}}+\beta_{8} \text { TOBINSQ }_{\mathrm{it}}+e_{\mathrm{t}}
\end{aligned}
$$

\begin{tabular}{|c|c|c|}
\hline Panel 2(A) & DIV & DIV \\
\hline DIRFLN & $(0.208)^{*}$ & \\
\hline FD3 & & $(0.338)^{* *}$ \\
\hline TALOG & -0.256 & -0.303 \\
\hline FINLEV & 0.036 & 0.09 \\
\hline MARTOBOOK & 0.228 & 0.245 \\
\hline ROA & -0.289 & -1.095 \\
\hline RETE & $3.48^{* * *}$ & $3.58^{* * *}$ \\
\hline CASHHOL & $13.506^{* *}$ & $14.333^{* *}$ \\
\hline TobinsQ & $(0.108)^{*}$ & $(0.112)^{*}$ \\
\hline Adjusted R-Square & 0.158 & 0.157 \\
\hline Panel 2(B) & DIVEARN & DIVEARN \\
\hline DIRFLN & $(0.028)^{* *}$ & \\
\hline FD3 & & $(0.045)^{* *}$ \\
\hline TALOG & 0.053 & $0.057^{*}$ \\
\hline FINLEV & 0.014 & 0.015 \\
\hline MARTOBOOK & $0.001^{* *}$ & -0.001 \\
\hline $\mathrm{ROA}$ & 1.106 & $1.146^{* *}$ \\
\hline RETE & 0.105 & 0.098 \\
\hline CASHHOL & -0.097 & -0.104 \\
\hline TobinsQ & 0.012 & 0.012 \\
\hline Adjusted R-Square & 0.004 & 0.003 \\
\hline Panel 2(C) & DIVTA & DIVTA \\
\hline DIRFLN & $(0.006)^{*}$ & \\
\hline FD3 & & $(0.001)^{* * *}$ \\
\hline TALOG & $0.008^{* * *}$ & $0.007^{* * *}$ \\
\hline FINLEV & 0.001 & 0.001 \\
\hline MARTOBOOK & 0.005 & 0.005 \\
\hline $\mathrm{ROA}$ & $0.673^{* * *}$ & $0.668^{* * *}$ \\
\hline RETE & $(0.039)^{* * *}$ & $(0.039)^{* * *}$ \\
\hline CASHHOL & -0.003 & -0.001 \\
\hline TobinsQ & $0.002^{*}$ & $0.001^{*}$ \\
\hline Adjusted R-Square & 0.663 & 0.661 \\
\hline
\end{tabular}

Table 5 Alternative board gender diversity index and dividend payout policy

***, *** ${ }^{*}$ Significance at $1 \%, 5 \%$ and $10 \%$ 
Panel 2 (B)

$$
\begin{aligned}
\text { DIVEARN }= & \beta_{0}+\beta_{1} \text { DIRFLN }_{\mathrm{it}}+\beta_{2} \text { TALOG }_{\mathrm{it}} \\
& +\beta_{3} \text { FINLEV }_{\mathrm{it}}+\beta_{4} \text { MARTOBOOK }_{\mathrm{it}}+\beta_{5} \text { ROA }_{\mathrm{it}} \\
& +\beta_{6} \text { RETE }_{\mathrm{it}}+\beta_{7} \text { CASHHOL }_{\mathrm{it}}+\beta_{8} \text { TOBINSQ }_{\mathrm{it}}+e_{\mathrm{t}} \\
\text { DIVEARN }= & \beta_{0}+\beta_{1} \text { FD }_{\mathrm{it}}+\beta_{2} \text { TALOG }_{\mathrm{it}} \\
& +\beta_{3} \text { FINLEV }_{\mathrm{it}}+\beta_{4} \text { MARTOBOOK }_{\mathrm{it}}+\beta_{5} \text { ROA }_{\mathrm{it}} \\
& +\beta_{6} \text { RETE }_{\mathrm{it}}+\beta_{7} \text { CASHHOL }_{\mathrm{it}}+\beta_{8} \text { TOBINSQ }_{\mathrm{it}}+e_{\mathrm{t}}
\end{aligned}
$$

$$
\begin{aligned}
\text { Panel } 2(C) & \\
\text { DIVTA }= & \beta_{0}+\beta_{1} \text { DIRFLN }_{\text {it }}+\beta_{2} \text { TALOG }_{\text {it }} \\
& +\beta_{3} \text { FINLEV }_{\text {it }}+\beta_{4} \text { MARTOBOOK }_{\text {it }}+\beta_{5} \text { ROA }_{\text {it }} \\
& +\beta_{6} \text { RETE }_{\text {it }}+\beta_{7} \text { CASHHOL }_{i t}+\beta_{8} \text { TOBINSQ }_{\text {it }}+e_{\mathrm{t}} \\
\text { DIVTA }= & \beta_{0}+\beta_{1} \text { FD }_{\text {it }}+\beta_{2} \text { TALOG }_{i t} \\
& +\beta_{3} \text { FINLEV }_{\text {it }}+\beta_{4} \text { MARTOBOOK }_{\text {it }}+\beta_{5} \text { ROA }_{\text {it }} \\
& +\beta_{6} \text { RETE }_{\text {it }}+\beta_{7} \text { CASHHOL }_{i t}+\beta_{8} \text { TOBINSQ }_{\text {it }}+e_{\mathrm{t}}
\end{aligned}
$$

To check the robustness of results of panel 1, alternative gender diversity measures are considered in panel 2 to examine the impact of gender diversity on dividend payout ratio, dividend to total assets and also to investigate that whether alternate gender diversity impacts the board's decision to pay or not to pay dividends. De Cabo et al. [13] opined that one is just representation and three has a voice; that is why FD3 is included in panel 2 to examine the impact of three or more female directors on the dividend. The results are consistent with the output of Panel 1. FD1 is not a significant predictor in panel 1, whereas in panel 2 FD3 is a significant predictor.

\section{Conclusion}

India, being an emerging economy, differs in terms of institutional settings from other developed nations, and due to India's growth opportunities, world economies are looking toward India as a nation of investment opportunities. Regulators in India are making major amendments in Legislations to include women representation on the boards, and dividend payout is an area that has not been given much attention by the scholars, especially from the Indian perspective. Thus, this study is first of its kind is novel in its approach and will help future researchers. In this study, an attempt is made to determine the impact of gender diversity on the board on dividend payouts. Researches in this area are scant, and that too focus is on developed countries. This study extends the research line and shows the negative impact of the diverse board on the payout ratio. In recent times, it is evidenced that number of female directors is increasing. This study has two considerations: (1) many companies are now very much adhering to corporate governance norms and (2) the issue of gender diversity on board is gaining importance worldwide. It has policy implications also. Policymakers should provide an equal platform for female senior professionals for their career development. Gender diverse boards may provide a different perspective on various issues. Based on this study, the board with a higher proportion of female directors provide a higher payout ratio. It appears that the business environment in India pushes the board member to endorse aggressive policies in context to the dividend.

Furthermore, results also indicate that the board of weak institutional setting country does not adopt dividend as a tool for minimizing agency conflicts. The study's findings complement previous research that has shown that a higher dividend is paid by the board, which is diverse in terms of gender [44]. A study by Botelho and Abraham [8] suggests that financial education is one of the parameters that are considered to minimize genderbased risk aversion. This could not be considered in the study due to the lack of data on directors' financial education. In the future, this can be interesting to account for this variable and examine how the financial education of directors affects the dividend payout ratio. 


\section{Implications and limitations}

Our study contributes to the theory on board diversity and dividend payout ratio by providing new understandings into the relationship of female representation on boards and the profit which is distributed to the shareholders. Historically, India has been a nation witnessing lower female directors on board; therefore, the government had to take measures to put a quota system for promoting female representation on board which indicated positive association with the percentage of profits distributed to the shareholders. There is a "bird in the hand argument," which implies that shareholders prefer to take certain cash flows in the form of dividends rather than uncertain capital gains. So, from the perspective of shareholders, gender diversity will be a favorable factor. The study results exhibit the importance of gender diversity on boards to the policymakers of the country as Indian regulators are taking various measures to promote gender diversity. The results of the study indicate that the composition of BOD affects the dividend payout ratio. Firms, where the female concentration is more on board, are inclined toward paying higher dividends against the ones with lesser female directors on board. Also, the results are checked for robustness. The robustness of the results has been tested by employing alternate gender diversity measures. This study will contribute to the growing literature on gender diversity in the area of corporate governance. The results would also be useful to the regulators, top management of firms, brokers, analysts, and investors of the company. Regulators can also assess whether promoting gender diversity on board impacts the firm's dividend payout ratio. In the research work of gender diversity, there always exist issues of endogeneity [38] so, this study can be extended by applying econometric models to address endogeneity issues.

\section{Abbreviations}

BOD: Board of Directors; SEBI: Securities and Exchange board of India; CEO: Chief Executive Officer; NSE: National Stock Exchange; DPR: Dividend payout ratio; CMIE: Centre for Monitoring Indian Economy; ROA: Return on assets; FD: Female Director; MB: Market to book.

\section{Acknowledgements}

The authors thank the editor and anonymous reviewers for their valuable time and comments on the article.

\section{Authors' contributions}

"KM" prepared the conceptual framework and did the analysis of the study, $\mathrm{KM}^{2}$ conducted literature review for the study, SSJ collected the data for the study wrote the Implications and Limitations of the study." All authors have read and approved the manuscript.

\section{Funding}

The authors declare that no funding from any agency was received for the study.

\section{Availability of data and materials}

Data are available on request; the data used in the study are extracted from Bloomberg Professional Account, CMIE Prowess, and Company Annual reports.

\section{Declarations}

Competing interests

The authors declare that there are no competing interests.

\section{Author details}

${ }^{1}$ Finance and Accounting, Jaipuria Institute of Management, Indore, India. ${ }^{2}$ GITAM School of Business, GITAM (Deemed to be University), Bengaluru Campus, Bengaluru, India. ${ }^{3}$ Marketing, Jaipuria Institute of Management, Indore, India.

Received: 14 August 2020 Accepted: 26 April 2021

Published: 1 July 2021

\section{References}

1. Almumani MAY (2018) An empirical study on effect of profitability ratios and market value ratios on market capitalization of commercial banks in Jordan. Int J Bus Soc Sci 9(4):39-45

2. Atanassov J, Mandell AJ (2018) Corporate governance and dividend policy: evidence of tunneling from master limited partnerships. J Corp Finan 53:106-132

3. Banerjee A, De A (2015) Capital structure decisions and its impact on dividend payout ratio during the pre-and post-period of recession in Indian scenario: an empirical study. Vision 19(4):366-377

4. Ben-Amar W, Chang M, Mcllkenny P (2017) Board gender diversity and corporate response to sustainability initiatives: evidence from the carbon disclosure project. J Bus Ethics 142(2):369-383

5. Benavides J, Berggrun L, Perafan H (2016) Dividend payout policies: evidence from Latin America. Financ Res Lett 17:197-210

6. Benjamin SJ, Zain MM (2015) Corporate governance and dividends payout: are they substitutes or complementary? J Asia Bus Stud 9(2):177-194

7. Ben-Nasr H (2015) Government ownership and dividend policy: evidence from newly privatised firms. J Bus Financ Acc 42(5-6):665-704

8. Botelho TL, Abraham M (2017) Pursuing quality: how search costs and uncertainty magnify gender-based double standards in a multistage evaluation process. Adm Sci Q 62(4):698-730

9. Byoun S, Chang K, Kim YS (2016) Does corporate board diversity affect corporate payout policy? Asia Pac J Financ Stud 45(1):48-101

10. Bzeouich B, Lakhal F, Dammak N (2019) Earnings management and corporate investment efficiency: does the board of directors matter? J Financ Rep Account 17(4):650-670

11. Campbell K, Vera AM (2010) Female board appointments and firm valuation: Short and long-term effects. J Manage Governance 14(1):37-59

12. Chen J, Leung WS, Goergen M (2017) The impact of board gender composition on dividend payouts. J Corp Finan 43:86-105

13. de Cabo RM, Terjesen S, Escot L, Gimeno R (2019) Do 'soft law' board gender quotas work? Evidence from a natural experiment. Eur Manag J 37(5):611-624

14. Dempsey M, Gunasekarage A, Truong TT (2019) The association between dividend payout and firm growth: Australian evidence. Account Finance 59(4):2345-2376

15. Dogru T (2017) Under-vs over-investment: hotel firms'value around acquisitions. Int J Contemp Hosp Manag 29(8):2050-2069

16. Duygun M, Guney Y, Moin A (2018) Dividend policy of Indonesian listed firms: the role of families and the state. Econ Model 75:336-354

17. Fan $Y$, Jiang $Y$, Zhang X, Zhou $Y$ (2019) Women on boards and bank earnings management: from zero to hero. J Bank Finance 107:105607

18. Garcia-Torea N, Fernandez-Feijoo B, de la Cuesta M (2016) Board of director's effectiveness and the stakeholder perspective of corporate governance: Do effective boards promote the interests of shareholders and stakeholders? BRQ Bus Res Q 19(4):246-260

19. Gallego-Alvarez I, Ortas E, Vicente-Villardón JL, Álvarez Etxeberria I (2017) Institutional constraints, stakeholder pressure and corporate environmental reporting policies. Bus Strateg Environ 26(6):807-825

20. Gim J, Jang SS (2020) Share repurchases and stock market reactions: messages from the restaurant industry. Int J Hosp Manag 86:102457 
21. Grey C, Flynn A, Donnelly R (2020) Management compensation contracts and distribution policies in the US technology sector. Int Rev Financ Anal 67:101403

22. Gugler K (2003) Corporate governance, dividend payout policy, and the interrelation between dividends, R\&D, and capital investment. J Bank Finance 27(7):1297-1321

23. Gul FA, Srinidhi B, Ng AC (2011) Does board gender diversity improve the informativeness of stock prices? J Account Econ 51(3):314-338

24. Gyapong E, Ahmed A, Ntim CG, Nadeem M (2019) Board gender diversity and dividend policy in Australian listed firms: the effect of ownership concentration. Asia Pacific J Manag 1-41

25. Hassan Y, Hijazi R, Naser K (2017) Does audit committee substitute or complement other corporate governance mechanisms. Manag Audit J 32(7):658-681

26. He Z, Wintoki MB (2016) The cost of innovation: R\&D and high cash holdings in US firms. J Corp Financ 41:280-303

27. Hiller JS, Shackelford SJ (2018) The firm and common pool resource theory: understanding the rise of benefit corporations. Am Bus Law J 55(1):5-51

28. Huang W, Paul DL (2017) Institutional holdings, investment opportunities and dividend policy. Q Rev Econ Finance 64:152-161

29. Jiraporn $P$, Leelalai $V$, Tong $S$ (2016) The effect of managerial ability on dividend policy: how do talented managers view dividend payouts? Appl Econ Lett 23(12):857-862

30. Kim H, Kim JH (2019) Voluntary zero-dividend paying firms: characteristics and performance. Appl Econ 51(50):5420-5446

31. Labhane NB, Das RC (2015) Determinants of dividend payout ratio: evidence from Indian companies. Bus Econ Res 5(2):217-241

32. Labhane NB, Mahakud J (2016) Determinants of dividend policy of Indian companies: a panel data analysis. Paradigm 20(1):36-55

33. Landry EE, Bernardi RA, Bosco SM (2016) Recognition for sustained corporate social responsibility: female directors make a difference. Corp Soc Responsib Environ Manag 23(1):27-36

34. Lara JMG, Osma BG, Mora A, Scapin M (2017) The monitoring role of female directors over accounting quality. J Corp Finan 45:651-668

35. Li WX, He TT, Marshall A, Tang GY (2019) An empirical analysis of accounting conservatism surrounding share repurchases. Eur Bus Rev 1-19

36. Manneh MA, Naser K (2015) Determinants of corporate dividends policy: evidence from an emerging economy. Int J Econ Financ 7(7):229-239

37. Nadeem M (2020) Does board gender diversity influence voluntary disclosure of intellectual capital in initial public offering prospectuses? Evidence from China. Corp Govern Int Rev 28(2):100-118

38. Nadeem M, Bahadar S, Gull AA, lqbal U (2020) Are women eco-friendly? Board gender diversity and environmental innovation. Bus Strateg Environ 29(8):3146-3161

39. Nadeem M, Suleman T, Ahmed A (2019) Women on boards, firm risk and the profitability nexus: Does gender diversity moderate the risk and return relationship? Int Rev Econ Financ 64:427-442

40. Nadeem M, Zaman R, Saleem I (2017) Boardroom gender diversity and corporate sustainability practices: evidence from Australian securities exchange listed firms. J Clean Prod 149:874-885

41. Naseem MA, Xiaoming S, Riaz S, Rehman RU (2017) Board attributes and financial performance: the evidence from an emerging economy. J Dev Areas 51(3):281-297

42. Pahi D, Yadav IS (2018) Role of corporate governance in determining dividend policy: panel evidence from India. Int J Trade Econ Financ 9(3):111-115

43. Panda B, Leepsa NM (2017) Agency theory: review of theory and evidence on problems and perspectives. Indian J Corp Govern 10(1):74-95

44. Pucheta-Martínez MC, Bel-Oms I (2016) The board of directors and dividend policy: the effect of gender diversity. Ind Corp Change 25(3):523-547

45. Saeed A, Sameer M (2017) Impact of board gender diversity on dividend payments: evidence from some emerging economies. Int Bus Rev 26(6):1100-1113
46. Singh AK, Singhania S, Sardana V (2019) Do women on boards affect firm's financial performance? Evidence from Indian IPO firms. Aust Account Bus Finance J 13(2):53-68

47. Solimene S, Coluccia D, Fontana S (2017) Gender diversity on corporate boards: an empirical investigation of Italian listed companies. Palgrave Commun 3:16109

48. Sridhar I, Jasrotia SS (2020) Board leadership and executive compensation: corporate governance in India. Int J Indian Cult Bus Manag 20(1):11-20

49. Sridhar I, Jasrotia SS (2021) CEO compensation and corporate governance: evidence from India. J Dev Areas 55(1):41-53

50. Tejedo-Romero F, Rodrigues LL, Craig R (2017) Women directors and disclosure of intellectual capital information. Eur Res Manag Bus Econ 23(3):123-131

51. Terjesen S, Couto EB, Francisco PM (2016) Does the presence of independent and female directors impact firm performance? A multi-country study of board diversity. J Manag Govern 20(3):447-483

52. Van Pelt T (2013) The effect of board characteristics on dividend policy. Unpublished working paper. Tilburg School of Economics and Management, Department of Finance, Tilburg University, The Netherlands, pp $1-62$

53. Wiley C, Monllor-Tormos M (2018) Board gender diversity in the STEM\&F sectors: the critical mass required to drive firm performance. J Leadersh Organ Stud 25(3):290-308

54. Yang P, Riepe J, Moser K, Pull K, Terjesen S (2019) Women directors, firm performance, and firm risk: a causal perspective. Leadersh Q 30(5):101297

55. Ye D, Deng J, Liu Y, Szewczyk SH, Chen X (2019) Does board gender diversity increase dividend payouts? Analysis of global evidence. J Corp Financ 58:1-26

56. Zalata AM, Ntim CG, Choudhry T, Hassanein A, Elzahar H (2019) Female directors and managerial opportunism: monitoring versus advisory female directors. Leadersh Q 30(5):101309

\section{Web Resources}

57. https://www.thehindubusinessline.com/companies/women-make-up15-of-board-seats-in-listed-indian-firms/article9969978.ece. Accessed 16 Sept 2019

58. https://www.thehindubusinessline.com/economy/indias-growth-inlast-5-years-has-been-transformational-shringla/article26587608.ece. Accessed 16 Sept

59. https://economictimes.indiatimes.com/sebi-makes-dividend-distributi on-policy-must-for-top-500-firms/articleshow/53191759.cms. Accessed 19 Sept 2019

60. http://www.indianboards.com/pages/index.aspx. Accessed 30 Aug 2019

61. https://www.credit-suisse.com/about-us-news/en/articles/media-relea ses/42035-201207.html

\section{Publisher's Note}

Springer Nature remains neutral with regard to jurisdictional claims in published maps and institutional affiliations.

\section{Submit your manuscript to a SpringerOpen ${ }^{\circ}$ journal and benefit from:}

- Convenient online submission

- Rigorous peer review

- Open access: articles freely available online

- High visibility within the field

Retaining the copyright to your article

Submit your next manuscript at springeropen.com 